\title{
Pre-germinative treatments and seed storage of Psidium cattleyanum Sabine morphotypes
}

\author{
Haron Victor Ferreira Camargo, Letícia Siqueira Walter, Mônica Moreno Gabira, Dagma Kratz \\ Universidade Federal do Paraná - UFPR, PR. E-mail: leticiasiqueira.walter@gmail.com
}

\begin{abstract}
This study aimed to evaluate the germination behavior of two morphotypes of $P$. cattleyanum submitted to storage and pre-germinative treatments. The experiment was designed in a factorial scheme $2 \times 3 \times 3$ (morphotypes $\mathrm{x}$ storage periods $\mathrm{x}$ pre-germinative treatments) completely randomized, using for each treatment 5 replicates with 30 seeds. The seeds were stored in semipermeable packages in a cold chamber at $5 \pm 2{ }^{\circ} \mathrm{C}$, for 14,45 , and 90 days. After each storage period, the seeds were submitted to treatments to overcome dormancy: immersion in water at $80^{\circ} \mathrm{C}$, kept in imbibition for 24 and $48 \mathrm{~h}$ and control, without any treatment. The seeds were arranged under moistened substrate in transparent plastic boxes and allocated in a germination chamber at $25{ }^{\circ} \mathrm{C}$ and photoperiod of $8 \mathrm{~h}$ for evaluation of germination percentage (G), germination speed index (GSI) and mean germination time (MGT). The red morphotype seeds showed higher germination percentages than the yellow morphotype and did not have a reduction in these values after 90 days of storage. MGT for yellow morphotype was lower in all pre-germinative treatments. The GSI had better results at 45 days in the control treatments and $24 \mathrm{~h}$ in immersion in water and 90 days for the three pre-germinative treatments. The red morphotype does not require pregerminative treatments, while the yellow morphotype presents better germination when the seeds are stored for 45 days and immersed in water at $80^{\circ} \mathrm{C}$ for $48 \mathrm{~h}$.
\end{abstract}

Keywords: Germination potential; red araçá; tegumentar dormancy; yellow araçá.

Tratamentos pré-germinativos e armazenamento de sementes de morfotipos de Psidium cattleyanum Sabine

\section{Resumo}

Objetivou-se avaliar o comportamento germinativo de dois morfotipos de $P$. cattleyanum submetidos a acondicionamento e tratamentos pré-germinativos. $O$ experimento foi delineado em esquema fatorial $2 \times 3$ x 3 (morfotipos $x$ períodos de armazenamento $x$ tratamentos de superação de dormência) inteiramente casualizado, utilizando-se para cada tratamento 5 repetições com 30 sementes. As sementes foram armazenadas em embalagens semipermeáveis em câmara fria a $5 \pm 2{ }^{\circ} \mathrm{C}$, durante 14,45 e 90 dias. Posteriormente a cada período de armazenamento as sementes foram submetidas a tratamentos para superação de dormência: imersão em água a $80{ }^{\circ} \mathrm{C}$ mantidas em embebição por 24 e 48 horas e testemunha, sem tratamento. As sementes foram dispostas sob substrato umedecido em caixas plásticas transparentes e alocadas em câmara de germinação a $25{ }^{\circ} \mathrm{C}$ e fotoperíodo de $8 \mathrm{~h}$ para avaliação da porcentagem de germinação (G), índice de velocidade de germinação (IVG) e tempo médio de germinação (TMG). As sementes do morfotipo vermelho apresentaram maior porcentagem de germinação em relação ao morfotipo amarelo e não tiveram redução nesses valores após 90 dias de armazenamento. O TMG para o morfotipo amarelo foi menor em todos os tratamentos pré-germinativos. O IVG teve melhores resultados aos 45 dias, nos tratamentos controle e $24 \mathrm{~h}$ em imersão em água, e aos 90 dias, para os três tratamentos pré-germinativos. 0 morfotipo vermelho não necessita de tratamentos pré-germinativos, enquanto o morfotipo amarelo apresenta melhor germinação quando as sementes são armazenadas por 45 dias e imersas em água a $80^{\circ} \mathrm{C}$ por $48 \mathrm{~h}$.

Palavras-chave: araçá amarelo; araçá vermelho; dormência tegumentar; potencial germinativo. 


\section{Introduction}

Popularly known as araçá, Psidium cattleyanum Sabine is a species native to Brazil (PATEL, 2012; REFLORA, 2020), and can also be found in Uruguay (FRANZON et al., 2009). There are two morphotypes of this species, differentiated by the color of the fruit in yellow (Ya-cy) or red (Irapuã) (ROCHA et al., 2020; PEREIRA et al., 2018). The species has a fleshy fruit, widely consumed by the avifauna (SILVA et al., 2011), and is recommended for areas in the process of restoration. In addition to their ecological importance, araçá fruits have the potential for commercialization, to supply the demand for their consumption in natura or in the form of agro-industry derivatives, such as jams (SANTOS et al., 2007). The fruits have a high concentration of phenolic compounds and secondary metabolites that act as antioxidants, also enabling their use in the pharmaceutical industry (PATEL, 2012; PEREIRA et al., 2018). Given its ecological and economic importance, the species has great potential for economic exploitation in small farms, being incorporated into preservation or agroforestry areas (HOSSEL et al., 2017).

Plants develop several strategies, according to their natural environment, so that germination occurs satisfactorily, resulting in radicle emission and development of normal seedlings (SHU et al., 2016; NONOGAKI, 2019). The fleshy fruit indicates that the dispersion of the species is barochoric and zoochoric. These types of dispersion increase the seed bank and, consequently, promote the formation of the seedling bank (OLIVEIRA, 2012). However, evaluating the seed bank of $P$. cattleyanum, Uowolo and Denslow (2008) stated that the species does not form a persistent seed bank, losing viability after 6.5 months.

Some species require pre-germinative treatments to reduce time and increase homogeneity in germination. Kumar (2016) indicates the use of pre-germinative treatments to increase the results of this species germination, such as immersion in water or sulfuric acid, at different times and concentrations, or mechanical scarification. It is known that araçá seeds have dormancy; however, there is no consensus on the best method for overcoming it, being suggested cold stratification for yellow araçá (TREVISAN et al.,
2004) and the need for light presence for the red araçá (SANTOS et al., 2004).

Given the economic potential of the species and its ecological importance, studies are needed on conservation, adequate storage (SILVA et al., 2011), and overcoming dormancy, thus enabling their availability and use throughout the year. Therefore, this study aimed to evaluate the germination behavior of two morphotypes of $P$. cattleyanum submitted to different storage times and pre-germinative treatments.

\section{Material and Methods}

The seeds of $P$. cattleyanum were donated by the Chauá Society, located in Campo Largo/PR. They collected the seeds from ten parents trees in the second half of February 2018. According to Köppen (ALVARES et al., 2013), the climate of the region is $\mathrm{Cfb}$, a temperate climate with uniformly distributed rains, mild summer, and severe and frequent frosts. The storage period and evaluations were carried out at the Laboratório de Sementes Florestais of UFPR, Campus Botânico, Curitiba/PR, in February 2018.

The seeds were processed in the Forest Seed Laboratory. For this, we manually macerated the fruits in a fine-mesh sieve with running water to expel the seeds. After the washing process, the seeds were arranged to dry outdoors for $24 \mathrm{~h}$ and then packed in semipermeable packaging in the cold chamber.

Initially, we determined the weight of 1,000 seeds, the number of seeds per kilo, and seed moisture content, following the methodologies described in the Rules for Seed Analysis - RAS (BRASIL, 2009). We evaluated the seed moisture content following the drying method in an oven at $105{ }^{\circ} \mathrm{C}$ for $24 \mathrm{~h}$. For the determination of biometrics characteristics, we measured the length, width, and thickness of 50 seeds of each morphotype with a digital caliper with an accuracy of $0.05 \mathrm{~mm}$. We considered the length as the extent of the hilum up to the base of the seed, in the longitudinal direction; the width in the transverse direction of the seed, in the area of smaller seed diameter; and the thickness also in the transverse direction, in the area with the largest diameter of the seed.

The seeds were submitted to three storage times $(14,45$, and 90 days) in semipermeable packages kept in a cold chamber at $5 \pm 2{ }^{\circ} \mathrm{C}$. After each storage period, the seeds were submitted to three treatments to overcome 
dormancy. The seeds were placed in containers with water initially at $80{ }^{\circ} \mathrm{C}$, without the maintenance of this temperature, for 24 and 48 h. The seeds of the control treatment did not undergo pre-germination treatments.

For germination evaluation, after pregerminative treatments, the seeds were placed to germinate in transparent acrylic boxes (gerbox ${ }^{\circledR}$ ), using germitest ${ }^{\circledast}$ paper towels as substrate. The boxes with seeds were kept in BOD germination chambers (Biochemical Oxygen Demand), at $25^{\circ} \mathrm{C}$ and photoperiod of $8 \mathrm{~h}$. As response variables, we calculated germination percentage (G), germination speed index (GSI) (MAGUIRE, 1962), and mean germination time (MGT) (LABOURIAU; AGUDO, 1987).

The experiment was designed in a factorial scheme $2 \times 3 \times 3$ (morphotypes $\times$ storage periods $x$ dormancy overcoming treatments) completely randomized, using for each treatment 5 replicates with 30 seeds. The data were submitted to analysis of Bartlett's homogeneity and Shapiro-Wilk's normality. If normality and homogeneity of the data were confirmed, they were submitted to variance analysis (ANOVA), followed by the Tukey test $(P<0.05)$ (TUKEY, 1977). The analyses were performed with the aid of the Rbio software (BHERING, 2017).

\section{Results and Discussion}

The seed lot used had $12.99 \mathrm{~g} /$ thousand seeds, accounting for 76,982 seeds $/ \mathrm{kg}$. The initial seed moisture content was $13.95 \%$ for the red araçá and $12.55 \%$ for the yellow araçá. After 45 and 90 days of cold chamber storage, the humidity of the red and yellow araçá were 13.34 and $12.01 \%$ for 45 days and 15.46 and $14.03 \%$ for 90 days, respectively. Both values are higher than those observed by Silva et al. (2011) for seeds of the same species $(7.1 \%)$ at the time of packaging, indicating that the species can tolerate lower levels of desiccation. The same authors also observed a subtle increase in the moisture content of the seeds when stored in semipermeable packages in a cold chamber, due to the exchange of water between the seeds and the environment (MASETTO et al., 2014). The maintenance of the adequate degree of moisture during seed storage is important for its viability (CARVALHO et al., 2006), this characteristic is intrinsic to each species, and its knowledge is determinant for the establishment of sexual propagation protocols at the commercial level.

The red araçá seeds have a length of 4.10 $\mathrm{mm}( \pm 0.45 \mathrm{~mm})$, a width of $3.21 \mathrm{~mm}( \pm 0.36$ $\mathrm{mm})$ and thickness of $1.93 \mathrm{~mm}( \pm 0.30 \mathrm{~mm})$. The yellow morphotype has a length of $3.67 \mathrm{~mm} \mathrm{(} \pm$ $0.36 \mathrm{~mm})$, a width of $2.81 \mathrm{~mm}( \pm 0.30 \mathrm{~mm})$, and a thickness of $2.03 \mathrm{~mm}( \pm 0.27 \mathrm{~mm})$. These values indicate that the seeds of $P$. cattleyanum are smaller than the seeds of other species of the same genus, such as $P$. sobralianum (length of 5.0 - $7.0 \mathrm{~mm}$ ) (FREITAS et al., 2018) and P. guajava (length of $2.70-5.25 \mathrm{~mm}$ ) (MISHRA et al., 2018). The size and shape of seeds are related to their dispersal strategy and are determinant for the establishment of seed or seedling banks. This information is relevant for species differentiation, as well as for understanding dispersal strategies and physiological mechanisms (SILVA; MÔRO, 2008).

All factors influenced the germination percentage of the seeds, but there was no interaction between the three factors simultaneously (Table 1). There was a significant interaction between the three factors analyzed; However, only for the GSI, there were no significant interactions between morphotype $x$ dormancy and morphotype $\mathrm{x}$ storage. 
Table 1. Summary for the variance analysis for germination (G), mean germination time (MGT), and germination speed index (GSI) of Psidium cattleyanum seeds.

\begin{tabular}{ccccc}
\hline \multicolumn{5}{c}{ Medium Square (MS) } \\
\hline & GL & G & MGT & GSI \\
\hline Morphotypes & 1 & $2740.86^{* *}$ & $1366.53^{* *}$ & $4.58^{* *}$ \\
Dormancy & 2 & $591.11^{* *}$ & $114,04^{* *}$ & $0.54^{* *}$ \\
Storage & 2 & $1033.70^{* *}$ & $55.28^{* *}$ & $0.10^{* *}$ \\
Morphotypes x Dormancy & 2 & $640.49^{* *}$ & $8.15^{* *}$ & $0.01^{\text {ns }}$ \\
Morphotypes x Storage & 2 & $674.19^{* *}$ & $64.94^{* *}$ & $0.05^{\text {ns }}$ \\
Dormancy x Storage & 4 & $158.70^{\text {ns }}$ & $20.20^{* *}$ & $0.07^{* *}$ \\
Morphotypes x Dormancy x Storage & 4 & $181.04^{\text {ns }}$ & $1.68^{\text {ns }}$ & $0.04^{*}$ \\
Residues & 72 & 85.30 & 1.23 & 0.01 \\
Total & 89 & & & \\
Coefficient of variation (\%) & & 12.57 & 4.47 & 14.49
\end{tabular}

${ }^{*}$ significant at $\mathrm{p}<0.05 ;{ }^{* *}$ significant at $\mathrm{p}<0.01 ;{ }^{\text {ns }}$ non significant.

The red araçá presents a higher percentage of germination than the yellow araçá, and it requires $48 \mathrm{~h}$ immersed in water to equal the values observed for the other morphotype. Regarding storage time, we observed higher sensitivity of yellow araçá seeds, which showed a decrease in germination percentage when maintained for 90 days in a cold chamber (Table 2).

Table 2. Germination percentage of Psidium catleyanum seeds, red and yellow morphotypes, submitted to different storage times and dormancy overcoming treatments.

\begin{tabular}{ccccc}
\hline \multicolumn{4}{c}{ Germination (\%) } \\
\cline { 2 - 4 } $\begin{array}{c}\text { Dormancy } \\
\text { overcoming } \\
\text { (h) }\end{array}$ & \multicolumn{4}{c}{ Rorphotypes } \\
\hline 0 & 79.33 & aA & 57.78 & bB \\
24 & 78.22 & aA & 70.89 & bA \\
48 & 79.33 & aA & 75.11 & aA \\
\hline \multicolumn{4}{c}{} \\
\hline Storage times (days) & \multicolumn{4}{c}{ Morphotypes } \\
\cline { 2 - 4 } & 82.89 & aA & 70.89 & bA \\
\hline 14 & 77.33 & aA & 76.22 & aA \\
45 & 76.67 & aA & 56.67 & bB \\
\hline 0 &
\end{tabular}

Means followed by the same lowercase letters in rows and uppercase letters in columns do not differ by the Tukey test $(p<0.05)$.

In this study we observed that yellowaraçá seeds require a longer time submerged in water to achieve the same germination values as the other morphotype. This is due to the thicker integument, which promotes physical dormancy and prevents the entry of water (TUAN et al., 2019), which hinders the soaking process for the resumption of embryonic growth. However, different values were observed by Tomaz et al. (2011), in which yellow-araçá seeds presented better germination performance than those of red-araçá. On the other hand, the results obtained for the red araçá are consistent with that observed by Santos et al. (2004), in which seeds of the red morphotype reached $82 \%$ germination at 90 days after sowing.

The increase in seed storage time reduced the germination percentage, although it was significant only for the yellow morphotype. This behavior may be related to environmental conditions at the place where they were collected since environmental variations can influence the 
viability of seeds (SANTOS et al., 2015). Basic studies on the limit moisture levels supported by the species is an important tool to adapt the best drying and storage method of seeds, to maintain their viability (CARVALHO et al., 2006).

Tomaz et al. (2011) obtained $90 \%$ germination in $P$. cattleyanum seeds stored in a refrigerator for $48 \mathrm{~h}$ and immersed in water at 80 ${ }^{\circ} \mathrm{C}$ for 25 seconds. Silva et al. (2011), on the other hand, obtained initial germination percentage below $75 \%$ and significant decrease over time when evaluating seeds of the same species stored under different conditions for up to 1,107 days. As in the present study, for the red morphotype, Dresch et al. (2014) affirmed the application of pre-germinative treatments in seeds of $P$. guinean does not influence the germination of the species. The association of genetic characteristics and biochemical events is related to the vital processes of the seed, determining the maintenance or not of its viability (MARCOS FILHO, 2005; CARVALHO et al., 2006; TUAN et al., 2019). It is important to note that all seeds, regardless of storage method and period, are subject to reduced viability, which can be overcome by keeping seeds stored properly (CARVALHO et al., 2006; MASETTO et al., 2014).

The mean germination time (MGT) was higher for yellow-araçá seeds regardless of treatment to overcome dormancy or storage time (Table 3). For both morphotypes of araçá, the MGT reduced as the seeds were submitted to increasing time of pre-germinative treatment and, for the yellow-araçá, the MGT also decreased with the increase of the seed storage time.

Table 3. Mean germination time of Psidium catleyanum, red and yellow morphotypes, submitted to different storage times and dormancy overcoming treatments.

\begin{tabular}{|c|c|c|c|c|}
\hline \multicolumn{5}{|c|}{ Mean germination time } \\
\hline \multirow{2}{*}{$\begin{array}{c}\text { Dormancy } \\
\text { overcoming }(\mathrm{h})\end{array}$} & \multicolumn{4}{|c|}{ Morphotype } \\
\hline & \multicolumn{2}{|c|}{ Red } & \multicolumn{2}{|c|}{ Yellow } \\
\hline 0 & 23.40 & $\mathrm{bA}$ & 30.79 & $\mathrm{aA}$ \\
\hline 24 & 20.39 & bB & 27.41 & $a B$ \\
\hline 48 & 19.07 & $\mathrm{bC}$ & 28.05 & $a B$ \\
\hline Storage times & \multicolumn{4}{|c|}{ Morphotype } \\
\hline (days) & \multicolumn{2}{|c|}{ Red } & \multicolumn{2}{|c|}{ Yellow } \\
\hline 14 & 21.10 & bA & 31.32 & $\mathrm{aA}$ \\
\hline 45 & 20.55 & bA & 29.18 & $a B$ \\
\hline 90 & 21.23 & bA & 25.75 & $\mathrm{aC}$ \\
\hline \multirow{2}{*}{$\begin{array}{l}\text { Storage times } \\
\text { (days) }\end{array}$} & \multicolumn{4}{|c|}{ Dormancy overcome } \\
\hline & 0 & & 24 & 48 \\
\hline 14 & $29.14 \mathrm{aA}$ & & $.88 \mathrm{aB}$ & $24.26 \mathrm{cA}$ \\
\hline 45 & $24.39 \mathrm{aB}$ & & $99 \mathrm{bB}$ & $24.30 \mathrm{aA}$ \\
\hline 90 & $25.07 \mathrm{aB}$ & & $.72 \mathrm{bB}$ & $21.90 \mathrm{cB}$ \\
\hline
\end{tabular}

Means followed by equal lowercase letters in rows and uppercase letters in columns do not differ by Tukey test $(p<$ 0.05).

The MGTs observed in this study are lower than those observed by Gentil et al. (2018) for $P$. friedrichsthalianum seeds and those observed by Santos et al. (2004) for P. cattleyanum seeds submitted to different temperatures. The germination of the species is slow probably due to the mechanical barrier of the tegument, as observed by Freitas et al. (2018) for $P$. sobralianum, which may have been altered with the increase of imbibition time. According to
Masetto et al. (2014), the soaking of $P$. guinean seeds is effective for increasing germination, with a TMG higher than that found in the present study. The homogeneous germination, with the reduction of the average germination time, is another indication of the need to use pregermination treatments to obtain better results in germination, positively influencing the production of seedlings of the species. 
The germination speed index (GSI) shows that the pre-germination treatments were more efficient at 45 and 90 days of storage (Table 4).
For this variable, there was no influence of morphotypes.

Table 4. Germination speed index of Psidium catleyanum seeds, red and yellow morphotypes, submitted to different storage times, and dormancy overcoming treatments.

\begin{tabular}{|c|c|c|c|c|c|c|}
\hline \multicolumn{7}{|c|}{ Germination speed index } \\
\hline \multirow{2}{*}{$\begin{array}{l}\text { Dormancy } \\
\text { overcoming } \\
\text { (h) }\end{array}$} & \multicolumn{6}{|c|}{ Storage time (days) } \\
\hline & \multicolumn{2}{|c|}{14} & \multicolumn{2}{|c|}{45} & \multicolumn{2}{|c|}{90} \\
\hline 0 & 0.80 & bA & 1.09 & $\mathrm{aA}$ & 1.07 & $\mathrm{aA}$ \\
\hline 24 & 0.83 & bA & 1.08 & $\mathrm{aA}$ & 1.12 & $\mathrm{aA}$ \\
\hline 48 & 0.82 & bA & 0.82 & bB & 1.05 & $\mathrm{aA}$ \\
\hline
\end{tabular}

Means followed by equal lowercase letters in rows and uppercase letters in columns do not differ by Tukey test $(p<$ 0.05).

The GSI observed in this study are within the range obtained by Hossel et al. (2017) for $P$. cattleyanum seeds kept at different temperatures and are higher than that observed by Silva et al. (2011) for seeds of the same species stored in different ways. Porto et al. (2018), state that yellow araçá seeds maintain their viability for up to 330 days in Eppendorf ${ }^{\circledR}$ or TetraPak $^{\circledast}$ packages, but the authors did not report the moisture content of the seeds. The GSI values are important because they express the germination viability of the seeds submitted to different treatments, even if there are no differences between germination percentages (RANAL; SANTANA, 2006).

The results obtained in this study indicate the differences between the red and yellow morphotypes of $P$. cattleyanum. We demonstrated that each morphotype has intrinsic physiological differences that can influence the storage, germination, and even seedling formation. This information is important to support projects involving the use of seedlings of the species, ensuring greater efficiency in the storage and proper germination of seeds.

\section{Conclusion}

The red morphotype of araçá does not require pre-germination treatment, as it presents high germination potential even when stored for 90 days. The yellow morphotype of araçá has higher germination when immersed in water at $80{ }^{\circ} \mathrm{C}$ for $48 \mathrm{~h}$. Immersion in water for $48 \mathrm{~h}$ reduces the average germination time of the two morphotypes.

\section{Acknowledgments}

Non-governmental organization - Chauá Society for seeds donation.

\section{References}

ALVARES, C. A.; STAPE, J. L.; SENTELHAS, P. C.; GONÇALVES, J. L. M.; SPAROVEK, G. Köppen's climate classification map for Brazil. Meteorologische Zeitschrift, v. 22, n. 6, p. 711728, 2013. https://doi.org/10.1127/0941$\underline{2948 / 2013 / 0507}$

BRASIL. Ministério da Agricultura, Pecuária e Abastecimento. Regras para análise de sementes. Brasília: MAPA/ACS, 2009.

BHERING, L. L. Rbio: a tool for biometric and statistical analysis using the $\mathrm{R}$ Platform. Crop Breeding and Applied Biotechnology, v.17, p.187-190, 2017. https://doi.org/10.1590/198470332017v17n2s29

CARVALHO, L. R.; SILVA, E. A. A.; DAVIDE, A. C. Classificação de sementes florestais quanto ao comportamento no armazenamento. Revista Brasileira de Sementes, v.28, n.2, p.15-25, 2006. https://doi.org/10.1590/S0101$\underline{31222006000200003}$

DRESCH, D. M.; SCALON, S. P. Q.; SILVA, N. E. M.; MASETTO, T. E.; MUSSURY, R. M. Effect of pretreatments on seed germination and seedling growth in Psidium guineense Swartz. Agrociencia Uruguay, v.18, n.2, p.33-39, 2014.

FRANZON, C. R.; CAMPOS, L. Z. O.; PROENÇA, C. E. B.; SOUSA-SILVA, J. C. Aracás do gênero Psidium: principais espécies, ocorrência, 
descrição e usos. Embrapa Cerrados, 2009. 48p. (Documentos, 266)

FREITAS, A.F.; LOCENA, E.M.P.; BONILLA, O.H.; SILVA, A.L.; SAMPAIO, V.S. Seed, seedling and fruit morphology and seed germination of Psidium sobralianum plants of the São Francisco valley, Brazil. Caatinga, v.31, n.4, p.926-934, 2018. https://doi.org/10.1590/198321252018v31n415rc

GENTIL, D. F. O.; FERREIRA, S. A. N.; REBOUÇAS, E. R. Germination of Psidium friedrichsthalianum (O. Berg) Nied. Seeds under different temperature and storage conditions. Journal of Seed Science, v.40, n.3, p.246-252, 2018. https://doi.org/10.1590/2317-1545v40n3179617

HOSSEL, J. S. A. O.; HOSSEL, C.; WAGNER JÚNIOR, A.; MAZZARO, S. M.; FABIANE, K. C. Estratificação, substrato e temperatura na germinação de sementes de araçazeiro vermelho. Revista Brasileira de Tecnologia Aplicada nas Ciências Agrárias, v.10, n.3, p.83-88, 2017. https://doi.org/10.5935/PAeT.V10.N3.09

KUMAR, V. Effect of pre-sowing seed treatment on germination and seedling growth of Terminalia bellirica (Gaertn.) Roxb. Indian Journal of Ecology, v.43, n.1, p.233-238, 2016.

LABOURIAU, L. G.; AGUDO, M. On the physiology of seed germination in Salvia hispanica L. I. Temperature Effects. Anais da Academia Brasileira de Ciências, Rio de Janeiro, n.59, p.37$56,1987$.

MAGUIRE, J. D. Speed of germination-aid in selection and evaluation for seedlings emergence and vigor. Crop Science, v. 2, n. 1, p. 176-177, 1962.

https://doi.org/10.2135/cropsci1962.0011183X0 $\underline{00200020033 x}$

MARCOS FILHO, J. Fisiologia de sementes de plantas cultivadas. Piracicaba: FEALQ, 2005. 495p.

MASETTO, T. E.; NEVES, E. M. S.; SCALON, S. P. Q.; DRESCH, D. M. Drying, storage and osmotic conditioning of Psidium guineense Swartz Seeds. American Journal of Plant Sciences, v.5, p. 25912598, 2014.
MISHRA, D. S.; SINGH S.; SINGH, A. K.; YADAV V.; RAO, V. V. A.; SAROJ, P. L. Assessment of genetic diversity in guava. Indian Journal of Horticulture, v.75, n.3, p.362-368, 2018. https://doi.org/10.5958/0974-0112.2018.00063.4

NONOGAKI, H. Seed germination and dormancy: The classic story, new puzzles, and evolution. Journal of Integrative Plant Biology, v.61, n.5, p.541-563, 2019. https://doi.org/10.1111/jipb.12762

OLIVEIRA, O. S. Tecnologia de sementes florestais: espécies nativas. Curitiba: Ed. UFPR, 2012.

PATEL, S. Exotic tropical plant Psidium cattleianum: A review on prospects and threats. Reviews in Environmental Science and Biotechnology, v.11, n.13, p.243-248, 2012. https://doi.org/10.1007/s11157-012-9269-8

PEREIRA, E.; VINHOLES, J. C.; FRANZON, R.; DALMAZO, G.; VISSOTTO, M.; NORA, L. Psidium cattleianum fruits: A review on its composition and bioactivity. Food Chemistry, v.258, p.95-103, 2018.

https://doi.org/10.1016/j.foodchem.2018.03.024

PORTO, A. H.; WAGNER JÚNIOR, A.; KOSERA NETO, C.; SILVA, M.; STEFENI, A. R.; MOURA, G. C. Formas de armazenamento de araçazeiro. Colloquium Agrariae, v.14, n.1, p.26-34, 2018. https://doi.org/10.5747/ca.2018.v14.n1.a187

RANAL, M.A.; SANTANA, D.G. How and why to measure the germination process? Revista Brasileira de Botânica, v.29, n.1, p.1-11, 2006. https://doi.org/10.1590/S010084042006000100002

REFLORA. Flora do Brasil 2020: Psidium. Disponível em: http://floradobrasil.jbrj.gov.br/reflora/floradobra sil/FB10858. Acesso em: 30 Mar. 2020

ROCHA, C. H.; SOLDI, C.; BOFF, P.; BOFF, M. I. C. Chemical composition of the leaf oils from two morphotypes of Psidium cattleyanum at four phenological stages. Natural Product Research, p.1-4, 2020. https://doi.org/10.1080/14786419.2020.1721490 
SANTOS, C. M. R.; FERREIRA, A. G.; ÁQUILA, M. E. A. Características de frutos e germinação de sementes de seis espécies de Myrtaceae nativas do Rio Grande do Sul. Ciência Florestal, v.14, n.2, p.13-30, 2004. https://doi.org/10.5902/198050981802

SANTOS, M. S.; PETKOWICZ, C. L. O.; WOSIACKI, G.; NOGUEIRA, A.; CARNEIRO, E. B. B. Caracterização do suco de araçá vermelho (Psidium cattleianum Sabine) extraído mecanicamente e tratado enzimaticamente. Acta Scientiarum Agronomy, v.29, n.supl. p.617-621, 2007.

https://doi.org/10.4025/actasciagron.v29i5.737

SANTOS, M. A. C.; QUEIRÓZ, M. A.; BISPO, J. S.; DANTAS, B. F. Seed germination of Brazilian guava (Psidium guineense Swartz.). Journal of Seed Science, v.37, n.4, p. 214-221, 2015. https://doi.org/10.1590/2317-1545v37n4152933

SHU, K.; LIU, X. D.; XIE, Q.; HE, Z. H. Two Faces of One Seed: Hormonal Regulation of Dormancy and Germination. Molecular Plant, v.9, n.1, p.34-45, 2016.

https://doi.org/10.1016/i.molp.2015.08.010

SILVA, A.; PEREZ, S. C. J. G. A; PAULA, R. C. Qualidade fisiológica de sementes de Psidium cattleianum Sabine acondicionadas e armazenadas em diferentes condições. Revista Brasileira de Sementes, v.33, n.2, p.197-206, $2011 . \quad$ https://doi.org/10.1590/S0101$\underline{31222011000200001}$

SILVA, B. M. S.; MÔRO, F. V. Aspectos morfológicos do fruto, da semente e desenvolvimento pós-seminal de faveira (Clitoria fairchildiana R. A. Howard. - Fabaceae). Revista Brasileira de Sementes, Brasília, v. 30, n. 3, p. 195-201, 2008. https://doi.org/10.1590/S0101$\underline{31222008000300026}$

TOMAZ, Z. F. P.; GALARÇA, S. P.; LIMA, C. S. M; BETEMPS, D. L.; GONÇALVES, M. A.; RUFATO, A. R. Tratamentos pré-germinativos em sementes de araçazeiro (Psidium cattleyanum Sabine L.). Revista Brasileira de Sementes, v.17, n.1, p.6065, 2011.

TREVISAN, R.; ANTUNES, L. E. C.; GONÇALVES, E. D. Propagação de plantas frutíferas nativas. In: RASEIRA, M. C. B.; ANTUNES, L. E. C.; TREVISAN,
R. (Eds.) Espécies frutíferas do sul do Brasil. Pelotas: EMBRAPA, 2004. p.49-71.

TUAN, P. A.; SUN, M.; NGUYEN, T.; PARK, S.; AYELE, B. T. Molecular mechanisms of seed germination In: Sprouted grains: nutritional value, production and applications. 2019. 344p. https://doi.org/10.1016/B978-0-12-811525$\underline{1.00001-4}$

TUKEY, J. W. Exploratory data analysis. Reading, PA: Addison-Wesley, 1977.

UOWOLO, A. L.; DENSLOW, J. S. Characteristics of the Psidium cattleianum (Myrtaceae) seed bank in Hawaiian Lowland Wet Forests. Pacific Science, v.62, n.1, p.129-135, 2008. https://doi.org/10.2984/15346188(2008)62[129:COTPCM]2.0.CO;2 